\title{
MUSLIM WOMEN IN SOVIET CENTRAL ASIA
}

\section{Özge öz DöM*}

\begin{abstract}
$\ddot{O} z$
Sovyet Orta Asya'sında Müslüman Kadınlar

$\mathrm{Bu}$ çalışma, Sovyet rejiminin Müslüman kadınların yaşam biçimleri üzerindeki etkisini anlamak için Sovyet Orta Asya'sını tarihsel bir perspektiften analiz etmektedir. Özellikle, Orta Asya'daki Müslüman kadınları özgürleştirmek adına Sovyet yetkilileri tarafından yürürlüğe konan kanun ve politikaların temel nedenlerine odaklanmaktadır. Araştırmanın temel argümanı, Sovyet yetkililerinin hem kamusal hem de özel yaşam alanlarında Orta Asya kadınlarını ataerkil yapıdan kurtarmak için sahici bir niyeti olsa da, uygulanan politika ve uygulamaların temelde rejimin hayatta kalmasına yönelik olduğudur. Sovyet rejiminin ilk yıllarında kadınların kurtuluşu projesini çoğunlukla ideolojik niyetler şekillendirmiştir.
\end{abstract}

Anahtar kelimeler: Orta Asya, Sovyetler Birliği, kadının özgürleşmesi, Sovyet kadın politikaları, Sovyet Orta Asya

\begin{abstract}
This study analyzes the Soviet Central Asia from a historical perspective to understand the impact of the Soviet regime on Muslim women's lifestyles. It specifically focuses on the underlying reasons of laws and policies put into effect by the Soviet officials in the name of emancipating Muslim women in Central Asia. The main argument of the study is that even though the Soviet officials had a genuine intention for the emancipation of Central Asian women from the patriarchal structure both in the public and private spheres of life, the policies and their implementations were shaped in accordance with the basic motive of the regime to survive. In the first years of the Soviet regime, mostly ideological intentions shaped the women's emancipation project.
\end{abstract}

Key words: Central Asia, Soviet Union, women's emancipation, Soviet gender policies, Soviet Central Asia

\footnotetext{
* Arş. Gör., Ankara Yıldırım Beyazıt Üniversitesi, Siyaset Bilimi ve Kamu Yönetimi Bölümü, Ankara.E-posta: ozgeozdom@gmail.com

(Makale Gönderim Tarihi: 09.01.2018 - Makale Kabul Tarihi: 17.05.2018)
} 


\section{Introduction}

After the Bolshevik Revolution of 1917, USSR (Union of Soviet Socialist Republics) was founded claiming to establish the first Communist regime in the world. The new Union tried to solve the economic, political and social problems to establish strong and indestructible socialist regime in the long run. Many legal regulations and propaganda tools were used for this purpose. In Central Asia, as elsewhere in the Union, Soviet regime tried to achieve a union economy, establish a state, which is atheist, egalitarian and secular, and to create a Soviet people sharing the same values regardless of their linguistic, cultural and traditional differences. In addition to these, the Soviet Union tried to change, destroy, or solve the issues related to the traditional life style of Central Asian people.

"Women's emancipation" was one of the items on the Soviet agenda. Emancipation, throughout this article, refers the liberation of women from enslavement to men and from traditional boundaries and stereotypes with the help of entering into the workforce and elimination of religious customs with reference to Soviet definition. It seems that the Bolsheviks approach to "women's emancipation" focused on the economic and political spheres. They strongly believed that they needed women to create a Communist society and to make it last. Women were assumed to be the mothers of future Communist generations, and the Soviet Union encouraged political and economic participation of women all over the Union regardless of different characteristics of different regions. Both within the family and in social, economic and political life, women were supported to become a modern Soviet woman fulfilling their responsibilities and expected to make decisions based on her own free will. However, under the Soviet regime, what a woman should or should not do were defined within strict boundaries, according to the needs of time/the regime. Therefore, while Soviet Union tried to improve situation of women in the society, the regime also put them under heavy responsibilities and roles that women could not manage all the time. It seems to be there is a contradiction here in the Soviet vision, between seeing them as mothers (of the soviet generation), fulfilling their responsibilities and free will. Maybe soviet regime just wanted to switch women's loyalty and subservience from the family etc. to the new state, but not liberate them.

The literature on Soviet policies regarding women often revolve around the question of whether "women's emancipation" was achieved or not. More specifically, the motivations behind this Soviet project are analyzed. Was it ideologically or pragmatically driven? How vital woman emancipation was women's emancipation for the survival of the Soviet regime? How was it used to justify the Soviet policies? These are among the main questions discussed in 
the literature. Within this broad topic, the position of Muslim women of Central Asia make-up an interesting case. This paper will specifically focus on Soviet policies regarding women in Central Asian Republics for a few reasons. The paper consists of three parts. In the first part, I discuss the importance of this study, and the questions in mind regarding the subject. In the second part, after briefly discussing the pre-Soviet era, I focus on the position of Muslim women in Central Asia under Soviet regime in terms of legal, socio-cultural, economic and political spheres. And, in the last part, I evaluate the Soviet era policies regarding Muslim women.

In this paper, how being a Muslim and having strong cultural traditions affected the woman issue in Central Asia will be examined. The research question in mind is that; "was gender equality achieved under Soviet Union in Central Asia?" Answering the questions of "was the equality before law enough to create gender equality in the society?" and "did participation of work result in emancipation of women?" will be the other concerns of this paper. To answer these research questions, Muslim women under Soviet regime are analyzed. Legal, political, economic, and social regulations put into effect by Soviet Union are examined. The subtitles are chosen to underline the social engineering processes of the Soviet regime used for the purpose of women's emancipation Social engineering referred, as Massell points out, an evaluation, and coordination of the legal, associational, cultural and economic actions, while embracing the limitations of revolutionary legalism ${ }^{1}$.

The reason making Central Asian region important to study, and not any other Muslim country, is that people in this region experienced foreign domination in their lands and were forced to accept certain gender-based policies put into effect by foreign policy makers. These policies were from the above, and sometimes ignored the necessities and values of the people living in that region. Moreover, the atheist ideology of the Soviet regime saw religion (Islam) as a major threat. This is yet another reason that makes Central Asia unique in terms of the gender issue.

In the literature, on the one side, there are studies related to Soviet women and focusing on the ideological motivations of Soviet authorities on gender issue ${ }^{2}$. On the other side, there are studies on Central Asian women. These studies mainly focus on the pre-Soviet period Central Asian women who were characterized with bride price, child marriage, and isolation from the outside world via veil, polygamy, violence and male domination. After the

\footnotetext{
${ }^{1}$ Massell 2010, p. 189.

2 For further info; Engel 1987; Madison 1978; Ashwin 2000; Tay 1972; Kandiyoti 2007; Ruthchild 1983.
} 
arrival of Soviets to the region, feudal culture of the region was confronted with the Soviet ideology. Emancipation of women was the vital part of Soviet policies, because religious customs and traditions caused Central Asian women to be perceived as slaves by the new regime ${ }^{3}$.

Although there are many studies focusing on the Central Asian history and the transition period of these countries analyzing social, economic and cultural policies, very few scholars in Turkey have studied the subject of women in Central Asia; and these works mainly focused on the gender issue within a comparative perspective ${ }^{4}$. Therefore, this study aims at contributing to this literature by focusing on the life of women in the region, and how and why this changed or was changed during the Soviet era in a historical perspective.

\section{Muslim Women under Soviet Rule in Central Asia}

The situation of Muslim women changed in the Soviet era because women were the visible side of the Communist revolution. Leaders of Communist Party believed that emancipation of women was the first step for the emancipation of all.

Many scholars suggest that gender policies were not all about achieving gender equality, but about solving the current demographic, economic and ideological problems that the Soviet Union faced ${ }^{5}$. From the beginning of their rule, I believe that Soviet leaders tried hard to liberate women in all the regions of the country. The ideal was to equalize woman with man in the economic, social and political spheres. To do so, Soviet leaders provided moral and material support for helping women in their role as mothers and wives. However, the aims of Soviet Union are regarding women's emancipation different conditions and different ways in different regions of the Union. Lubin indicates that while Soviet policies regarding the female emancipation was a legal matter, in Central Asia, it was not about the social and economic norms, but a matter of religious and traditional society ${ }^{6}$.

Especially in the rural areas of Soviet Union, women had no public role and enjoyed only a few rights. They had no right to divorce, for example. Under Islamic law, they had formal rights in theory, but in practice, it was difficult to enjoy these rights, if not impossible. The very first duty of the woman was

\footnotetext{
${ }^{3}$ See also; Massell 1974; Heer \& Youssef 1977; Northrop 2004, p. 33; Sahadeo \& Zanca 2007; Women, Islam and the State, 1991; Corcoran-Nantes 2005.

${ }^{4}$ See also; Acar \& Güneş-Ayata 2000; Dalkesen 2007; Saktanber \& Özataş-Baykal 2000, p. 229248.

${ }^{5}$ Lubin 1981, p. 186.

${ }^{6}$ Lubin 1981, p. 182.
} 
childbearing, i.e. having a large number of sons for the well-being of the family. Health care provided to women was primitive. It was expected of women to work and give birth at the same time. These circumstances led to infant mortality rate being rather high in Central Asia. In addition, physical punishment to women was common. It was claimed by Massell that, "a husband catching a runaway wife might bite off her nose, and the branding of genitals in cases of female infidelity was also discovered"7.

Massell points out that Central Asian women were perceived by society, and by themselves as "the lowest of the low," "the most oppressed of the oppressed," "the most enslaved of the enslaved" 8 . Therefore, he made five assumptions regarding Central Asia and Central Asian women. Firstly, every society has antagonisms that would be put an end to by communism. Secondly, in Central Asia, two main reasons stood out for the lack of social struggle; the process of struggle could be masked by the notion of solidarity, and if the parties failed to behave in an expected manner, the problem could be solved by the strong kinship relations before it caused fragmentation. Therefore, there was a need for a different approach towards Central Asia. Thirdly, Muslim traditions were a unique target for revolutionary purposes, and women could be the main respondents of these purposes. Fourthly, women needed to be free from the chains of tradition, so that they could actively take part in the revolution. Lastly, female resentment and discontent would make women the revolutionary force in Central Asia.

Soviet Union had to eliminate all above-mentioned mentality of women's subordination to achieve its purposes. For Soviet leaders, it was not possible to build a Socialist state without liberating women. So, they tried to change the subordinate status of women by recruiting them into Soviet collective farms, factories and schools. It was their way to fight against the backwardness of Muslim women in Central Asia. Soviet authorities believed that, by eradicating the customs and traditions, they could finally transform the Central Asian women. The final goal was to make Central Asian women active Soviet citizens ${ }^{9}$. To achieve this end, negative elements in women's life in Central Asia were overemphasized. That intention of freeing women from all peculiarities they were born with does not necessarily guarantee desired results. As Keller claims, the Soviet policies for the emancipation of women in Uzbekistan had two components: freeing women from Muslim social and religious structures and placing them into the workforce. However, these emancipation attempts

\footnotetext{
${ }^{7}$ Kennedy-Pipe 2004, p. 94.

${ }^{8}$ Massell 2010, p. 93.

${ }^{9}$ Edgar 2003, p. 132.
} 
resulted in undesired outcomes when women were faced with the problem of creating balance between obeying the rules of the government, remaining royal to their families, communities, customs and, embracing their own opportunities to fulfill their desires. Therefore, women became the victims of the policies that were supposed to help improve their status in society ${ }^{10}$.

Soviet officials saw the Islam as the main cause of women's backwardness in Central Asia because they had to find such a component in the society to justify their policies as an atheist and Communist state. By this way, they have the chance to present themselves as the "saviors". So, they did not take what was written in the Koran or Sunna as a guide, their primary goal was to recruit women as the defenders of the new regime. There is quite a literature on whether Islam provided women more opportunities and enhance the position of women in the society, or it eradicated the women's status. However, this study does not focus on that issue; rather it underlines the latter view as the point of view of the Soviet Union ${ }^{11}$.

\subsection{Legal Framework}

In order to change the traditional way of life in Central Asia, the Soviet regime, made changes in the legal codes. Initial steps toward female emancipation were rather promising. In 1918, the first Family Code made women equal to men under the law. The code allowed women to choose their surname when they got married; gave illegitimate children the same legal rights as legitimate ones and eased the divorce process. Polygamy (polygyny), child marriage and bride wealth (kalym) were banned. This Code tried to achieve equality between husbands and wives, and to secularize marriage ${ }^{12}$.

In 1919, a Registry of Births, Marriage and Death was established in Turkestan ${ }^{13}$. In 1920, Islamic law (sharia law), and Islamic court system were replaced with secular law and courts ${ }^{14}$. The regime set an age limit of 18 for males, and 16 for girls to get married. The Code of 1920 put an end to the religious sanction of marriage. The equality between man and woman was guaranteed. Equal pay for equal work was legalized ${ }^{15}$.

\footnotetext{
${ }^{10}$ Keller 1998, p. 20.

${ }^{11}$ For further information see also; Kazemi 2000, p. 1; Esposito 1996; Raga' el-Nimr 1996; Mernissi 1991.

${ }^{12}$ Pascall and Manning 2000, p. 250.

${ }^{13}$ Corcoran-Nantes 2005, p.35.

${ }^{14}$ Kandiyoti 2007, p. 604.

${ }^{15}$ Edgar 2003, p. 138.
} 
New laws, also, concerned with the personal safety of women. Mistreatment and insulting of women were banned and forcing women to wear a veil became illegal ${ }^{16}$. In 1920, abortion was legalized. Women's Bureau of Communist Party (Zhenotdel) was established in $1919^{17}$. A circular was issued in 1926 to enhance female access to divorce via secular courts and it forbade the religious courts to hear divorce cases. In 1927, the commissariat issued a general call to form a "united front in the offensive against survivals of the old way of life for the liberation of women" no doubt in connection with the launching of the unveiling campaigns"18.

"The Decree in Defense of Mother and Child" in 1936 was a historical turning point. Family as the foundation of society was emphasized. Under this decree, abortion was illegalized, homosexuality was declared as a crime, divorce became difficult to obtain and rights of illegitimate children were revised $^{19}$. Protective labor legislation indicated that women should not work if it prevented their role as child bearers, and gave some special rights to pregnant women in the $1920 \mathrm{~s}^{20}$. It was assumed that financial support was needed for women to raise their children. This support was the key element of pro-natalist (the belief that a woman's worth is tied to conceiving and bearing children, and motherhood is a primary social role of women ${ }^{21}$ ) campaign for large families. In addition, visual material was used to emphasize the importance of motherhood and mothers ${ }^{22}$.

Central Asian Republics passed laws identifying and outlawing "crimes of custom" (byt or bytovye prestupleniia meaning social, everyday life) in the $1920 \mathrm{~s}^{23}$. In the 1930s, the Communist Party declared that emancipation of women was achieved. However, in the post-war years, it was stated, "the postwar years saw a steady increase in the absolute number of abortions, an indication of the state's failure to reach women through pro-natalist and antiabortion propaganda" 24 .

In 1941, a decree on taxing bachelors, single and childless citizens of the USSR tried to encourage birth. After World War II, the Soviet Union put pronatalist Family Law into effect. This law increased financial support for

\footnotetext{
${ }^{16}$ Northrop 2001, p. 119-122.

${ }^{17}$ Engel 1987, p. 787.

${ }^{18}$ Keller 1998, p. 23.

${ }^{19}$ Michaels 2001, p. 308.

${ }^{20}$ Evans 1981, p. 759.

${ }^{21}$ Ulrich \& Weatherall 2000.

${ }^{22}$ Michaels 2001, p. 320-323.

${ }^{23}$ Edgar 2003, p. 133.

${ }^{24}$ Michaels 2001, p. 326.
} 
pregnant women, mothers with many children, single mothers, and preserved motherhood. Honorary title of Mother Heroine (awarded to those with ten children or more) was introduced. This law aimed to increase population. "Motherhood Medal," Khrushchev's proposal consisted of two documents; the informational note (spravka) "on measures for increasing the population of the USSR" and the draft $u k a z$ "on measures to increase governmental support for women in childbirth and mothers with many children, and reinforcement of the protection of motherhood and childhood"25. As Pascall and Manning point out, legislative actions of Soviet Union on women's status took different forms as workers, partners, mothers, careers, and citizens, according to the needs of the time $^{26}$.

The emancipation of women was imposed from above by the Soviet government, for affecting revolutionary changes, while not being concerned about economic, social and demographic issues. After a certain time period, Soviet policy makers believed that women question in the Union was solved, and gender equality was achieved regardless of different starting points, nationalities and traditions of the various regions ${ }^{27}$. However, the major problem was the reluctance of local party officials to implement the laws they deemed to be against their way of life and religion ${ }^{28}$. So, regime's influence remained weak in Central Asia?, and the new laws remained unenforced in the long run.

\subsection{Socio-Cultural Arena}

In Central Asia, daughters were expected to protect family honor, have roles in the public domain, to be modest, and to obey their parents and husbands. Sons were perceived more valuable as they were productive laborers as well as the ones bringing wives and children into the family. They were expected to take care of their parents in their old age. However, daughters would leave their families once married ${ }^{29}$.

Women were to raise a child as a source of status and respect ${ }^{30}$. Muslim women were bound by the Sharia (law based on the holy book of Muslims, the Qur'an) which was perceived as the protector of women and guarantor of their moral and spiritual superiority as mothers, wives, and daughters. The nomadic and settled populations in the region had different interpretations of the law.

\footnotetext{
${ }^{25}$ Nakachi 2006, p. 40-47.

${ }^{26}$ Pascall and Manning 2000: p. 260.

${ }^{27}$ Lubin 1981, p. 182-183.

${ }^{28}$ Corcoran-Nantes 2005, p. 41.

${ }^{29}$ Edgar 2003, p. 135.

${ }^{30}$ Massell 2010, p. 108.
} 
Women in nomadic areas enjoyed more autonomy both in public and private spheres, as compared to women in settled areas ${ }^{31}$. The division of labor and tasks that women were handling gave them more freedom in rural areas, as compared to urban areas. Especially in the urban areas of Central Asia, women were not allowed to walk in the streets without male escort, when they did, they were expected to keep silent and segregated. A Turkmen saying clearly shows this view: "The world is a man's house, while the house is a woman's world"32.

Soviet leaders attempted to eliminate these views, customs and practices that oppressed women. They believed that this was the very first step of establishing socialism. Policy makers initiated some reforms eradicating the Islamic marriage and family practices. Child marriage, bride wealth and polygamy were outlawed to free women from the bondage of oppressive customs and to make them visible in schools, collective farms and public organizations ${ }^{33}$. The regime interpreted that women in Central Asia were bound up with traditions due to illiteracy, ignorance, and superstition in cultural roles $^{34}$. However, as Abazov points out, traditions in Central Asia were products of long-term experiences. For example, the extended family structure provided a social safety net. Therefore, arranged marriages helped the survival of social stability $^{35}$. The Soviet regime and Central Asian people did not view the traditional way of life in Central Asia from the same perspective. This was natural, but those different views made it difficult for the Soviet leaders to find a middle way and set a ground for their reforms. The daily life practices and customs of Muslim populations of Central Asia were unacceptable for the Soviet Union, and the destructive reforms initiated by the regime created resentment among the locals. Therefore, it was difficult to eliminate all the customs that defines Central Asian people. It was even more difficult for them to see their customs as crimes ${ }^{36}$.

The murders and harassments women faced with proved the inadequacy of legal sanctions to protect women. In 1938-1939, bride wealth and underage marriages cases of byt murders, sexual crimes and beatings of women increased ${ }^{37}$. Local police officers and prosecutors were not willing to punish these crimes, and this created the violence without any punishment. Men arrested for insulting unveiled women were sometimes released in as little as

\footnotetext{
${ }^{31}$ Corcoran-Nantes 2005, p. 36-37.

${ }^{32}$ Massell 2010, p. 101.

${ }^{33}$ Edgar 2006, p. 252-253.

${ }^{34}$ Massell 2010, p. 157.

${ }^{35}$ Abazov 2007, p. 216.

${ }^{36}$ Edgar 2003, p. 142.

${ }^{37}$ Northrop 2001, p. 126.
} 
two hours ${ }^{38}$. Moreover, child marriage was another problematic issue. Between the years 1925-1935, almost half of the social crimes were about child marriage. It can be argued that Soviet policy makers failed to abolish the traditional practices. Attendances of mosques increased, fasting for Ramadan remained as widespread practices, and unveiled women turned to veil once again. With the relaxation of anti-religious campaign in 1930s, women's duties as Muslim women were re-emphasized ${ }^{39}$.

Therefore, in Central Asia, the laws were not enough to guarantee women's emancipation. Men and women internalized the customs. It was difficult to cut the tie between women and customs. Therefore, Soviet policy makers attempted to cut this tie by fighting over the most visible characteristic of women in Central Asia, the veil.

\subsubsection{Family}

Women were treated as second-class members of the family in Central Asia. They were treated as the source of honor for the family. They had to be silent and obey the rules that their families and traditions had set for them. The relationship between a father and a daughter was limited. Mostly, the father decided the man whom his daughter married, as Turkmen saying indicates, "just as a cow does not choose the water she drinks so does a woman not choose her husband." In marriage, the woman was the object of the contract, not the subject ${ }^{40}$. Bride wealth and polygamy were, of course, in the picture.

After the Bolshevik Revolution, complete transformation of societies was envisioned. Transforming family structure was the part of it. Breaking up old family structures and formation of new ones was the motto of Soviet policies especially in the first decade of regime ${ }^{41}$. The Soviet Union, to achieve its end goal of transforming all society, tried to transform families in general, and mothers in particular. The distinct characteristics of the Soviet Union was the ideal of "the angel in the home", and encouragement of women to work ${ }^{42}$.

The 1918 Family Code gave the right to divorce to both women and men. Turkmen men perceived this law as an assault to Turkmen family. ${ }^{43}$ There is no doubt that men from other parts of the Central Asia also interpreted this law as Turkmen men. Consequences for women who dared to initiate divorce were

\footnotetext{
${ }^{38}$ Northrop 2001, p. 129-132.

${ }^{39}$ Keller 1998, p.31.

${ }^{40}$ Massell 2010, p. 121.

${ }^{41}$ Alexandrova 1946, p. 76.

42 Engel 1999, p. 359.

${ }^{43}$ Edgar 2003, p. 144.
} 
dire, ending mostly murder by their husbands or women would often commit suicide since they had nobody to take care of them following their divorce. As one can observe, the policies towards emancipation of women in the region did not always result in the desired outcomes. These outcomes became more and more unpredictable when the regime modified its policies over time. The family was used as a unit of analysis according to the needs of the time and the policies of the leaders. For example, in 1934 Stalin emphasized the family as the basic unit of socialist society when preservation of the family structures was needed for his economic policies. This declaration aimed at preserving families, decreasing divorces and abortions, and giving rise to the birthrate ${ }^{44}$. Kandiyoti claims that motherhood was promoted as a social duty as an explicit policy of Soviet Union. Pronatalist and maternalist policies put some value to the large families, especially in rural Central Asia. Central Asian women were encouraged to give birth with the awards like Heroine Mother and Motherhood Glory (given to those with seven to nine children) ${ }^{45}$.

The main failure of the Soviet Union regarding the family structure was that the regime ignored the customs and traditions that were the very basis of family formation in the region. Policies were shaped based on the ideology of the Soviet Union because at the end, the regime aimed at creating a society without any particularities like religion, tradition, and ethnicity. However, Central Asian people were not familiar with the regime and its ideals, so they should not have been expected to understand and internalize the reasons of reforms affecting family dynamics.

\subsubsection{Hujum}

Kamp expresses that for men and women in Central Asia, veiling was required by Islamic law and for a woman to reveal her face to men outside of her family would be committing a $\sin ^{46}$. One of the very basic tools of showing your religion and your commitment to it, veiling contains both traditional and moral meanings. The symbolic meanings attached to the veiling were attacked by Soviet officials who perceived the veil as the most important visible obstacle for the emancipation of women.

Soviet leaders saw the veil as the symbol of female inferiority, and veiled women as the symbol of backwardness of Central Asia. They portrayed veiling as "remnants of the past", "socially dangerous", and likely to "hinder the

\footnotetext{
${ }^{44}$ Kennedy-Pipe 2004, p. 97.

${ }^{45}$ Kandiyoti 2004, p. 607.

${ }^{46}$ Kamp 2006, p. 137.
} 
economic, political, and cultural growth of the republic" ${ }^{47}$. According to Soviet officials, the veiled women were prohibited from speaking to men and spent their days inside their houses taking care of children. In 1927, an attack on veiling started. This campaign was called Hujum. During this campaign, many women burned their veils in public ${ }^{48}$. It officially began in International Women's Day, on 8 March 1927. The event was described as following:

On the morning of March 8, a massive outpouring of crowds of Muslim women was organized in major Uzbek cities. Led by Zhenotdel activists, and protected by police cordons, they marched in procession to especially designated city squares. ... In all cases, the squares were reportedly outfitted with large daises, and decorated with flowers, oriental carpets, red banners, and placards with revolutionary slogans concerning the liberation of women. Military bands and native orchestras were provided to greet the female processions upon their arrival in the squares ${ }^{49}$.

Zhenotdel leaders and other participants blamed Islamic customs for women's backwardness and declared that emancipation of women would be achieved by Communism. Then, veiled women tore off their veils and burned them in public square ${ }^{50}$. However, as Kamp pointed out not all women were willing participants in this process. For instance, in Uzbekistan, internal police agency reported that the women who did not want to unveil in the unveiling meetings were threatened by political leaders, and party members. They, even, pulled women's veils off ${ }^{51}$.

Hujum was not only about unveiling women, but also about eliminating the traditional practices like bride-prices, polygyny, and other customs. Moreover, the campaign aimed to increase women's participation in the work force. Unveiling symbolized the conversion to the Soviet way of life. The unveiled women could attend literacy classes and party meetings, work in the public sphere, and could become active in political life. Unveiling helped the regime's aim of social transformation. Another interesting impact of unveiling was on the male party members. They had the chance to show their loyalty to the regime by unveiling their wives and daughters ${ }^{52}$. The women choosing to unveil were mostly from families where male members supported this idea; so

\footnotetext{
${ }^{47}$ Edgar 2003, p. 139.

${ }^{48}$ Edgar 2003, p. 132.

${ }^{49}$ Keller 1998, p. 24-25.

${ }^{50}$ Keller 1998, p. 25.

${ }^{51}$ Kamp 2006, p. 171.

${ }^{52}$ Edgar 2003, p. 136-137.
} 
very few Uzbek women decided to unveil due to their individual support for the new regime and its ideology ${ }^{53}$.

Furthermore, Hujum campaign offended many Muslims' values. There was violence against women, which cost thousands of lives. In February 1929, the newspaper Uzbekistanskaia Pravda wrote: "The murder of women has taken on a mass character. As of February 6,70 people have been murdered. Social crimes were also taking place: Kalym, giving girls in marriage, violence, rape of minors, etc" ${ }^{\prime \prime 4}$. This violence was a spontaneous crime of passion, and initiated to terrorize other women. Murders were planned to restore the honor and intimidate other women thinking of unveiling. So, some women re-veiled due to the fear of safety ${ }^{55}$. Soviet regime did not see the importance of veiling in terms of Central Asian customs. Many Muslims in the region interpreted Hujum as the storm to punish or test the Muslim believers, not as an emancipatory campaign over women ${ }^{56}$.

It should be noted that one exception in this case was Turkmenistan where veiling was absent. As Edgar points out, there was no Hujum in Turkmenistan. Under these circumstances, party officials emphasized the legal reforms transforming family life ${ }^{57}$.

Unveiling campaign was important for Soviet Union to influence Central Asian populations to emancipate women from the burdens of traditional way of life. The veil was a material that could be touched and gotten rid of and burned. It was a symbolic tool for the policies of the regime. However, the usage of this tool resulted in more resentment of the regime in the region. There was no dialogue between two parties in his process.

\subsection{Economic Arena}

In Central Asia, in pre-revolutionary years, traditionally husbands and fathers did not allow their wives or daughters to work outside the home due to their potential for contact with other men. Although women were the ones working in the field, carrying water, processing wools and making clothes, cooking, and raising the children, their work was invisible to men, and the community ${ }^{58}$.

\footnotetext{
${ }^{53}$ Kamp 2006, p. 148.

${ }^{54}$ Kamp 2006, p. 28.

${ }^{55}$ Kamp 2006, p. 187-201.

${ }^{56}$ Northrop 2004, p. 165.

${ }^{57}$ Edgar 2003, p. 133.

${ }^{58}$ Massell 2010, p. 98.
} 
The visibility of women became undeniable when the Soviet Union established a set of rules to guarantee women's place in the labor market. The Union promised equal pay, equal opportunities, and sanctions to prevent gender discrimination at work. Laws protected women. However, as so and so suggests that despite the laws and sanctions, higher rank positions were held mostly by $\operatorname{men}^{59}$.

The Soviet Union aimed at collectivization to establish agricultural sector without individual smallholdings, private property, and means of production. The desired result was the creation of state farm, the cooperative, and commune as the unit of production. It was expected that collectivization would affect women, because it would take the power away from the hands of the patriarchs. In addition, in collective farms, women's work would be visible due to direct registration, resulting in their economic independence ${ }^{60}$.

Women's participation in the labor force would be guaranteed with the provision of childcare services. High rate of labor participation was achieved, and women spent their time working outside the home instead of house caring ${ }^{61}$.

Another important turning point for the empowerment of women was Stalinist era when the Soviet Union tried to achieve economic independence, and there was a need to expand the labor force. The effect of labor conditions was ruled out for the welfare of the state ${ }^{62}$.

The main shortcoming regarding women's empowerment was experienced in 1928. Under the New Economic Plan (NEP), labor conscription was ended, unemployment rose, and women had difficulties finding a job and their dependency on men increased. Around the same time, government reduced childcare support ${ }^{63}$. The social services and industries helping women to liberate themselves from traditional customs were reduced. Zhenotdel was resolved, by doing this, the Soviet regime prevented women's protest of the industrialization process. Although the five-year plan promised to emancipate women through their inclusion into the paid labor force, in 1929 and 1930, female unemployment increased, and women were pushed to work in light industry and social services and to take care of domestic work ${ }^{64}$.

At the end of the Soviet period, women had become visible in all spheres of life. In Uzbekistan, for example, women constituted 50 percent of those

\footnotetext{
${ }^{59}$ Pascall and Manning 2000, p. 248.

${ }^{60}$ Croll 1981, p. 362.

${ }^{61}$ Pascall and Manning 2000, p. 245.

${ }^{62}$ Kennedy-Pipe 2004, p. 96.

${ }^{63}$ Farnsworth 1976, p. 300.

${ }^{64}$ Schrand 1999, p. 1455.
} 
employed by the government. 45 percent of local deputies were women. However, one should not forget that women mostly occupied the lower skilled jobs $^{65}$.

Lubin claims that the main reason for the emancipation of women in Central Asia was ideological in nature. While increasing women participation in the labor force, and the public sphere, the Soviet Union aimed for people to start to have smaller families. This means that they would be less concerned about domestic affairs, and economic independence of women would lead to the construction of Soviet ideals and values ${ }^{66}$.

\subsubsection{Double Burden}

Since the 1930s, women were engaged in both full-time waged labor and housework. Especially in the urban areas, they had to carry heavier responsibilities both in public and private spheres. Since the 1960s, women's role as mothers has been emphasized. The claim was that women were different from men biologically, so it was the natural for women to embrace motherhood roles $^{67}$. Child bearing was perceived as the natural role of women. Soviet authorities explained this by attaching women the qualities of being sensitive, delicate, and having the capacity for nurturing ${ }^{68}$. Combining the Soviet Union's attempts to make women a part of the labor force, and making them responsible for housework and child bearing, eventually, caused a "double burden"69. They had to work outside the home, and had to take care of the housework, without labor saving devices and they had to spend time in food lines. When the Soviet Union's policies to increase the birth-rate was added to the picture, the burden became an undeniable fact ${ }^{70}$.

Some authors such as Einhorn (1993), Lafont (2001), and Zellerer and Vyortkin (2004) argue that one should also consider triple burden in the Soviet Union. The women not only were expected to take care of household responsibilities and being part of the labor force, but also, they were encouraged to be politically active within the framework of Soviet ideology ${ }^{71}$.

The Soviet solution, within the framework of its ideology, was "to alleviate the burdens of domesticity, to improve public services, mechanize

\footnotetext{
${ }^{65}$ Kennedy-Pipe 2004, p. 100.

${ }^{66}$ Lubin 1981, p. 187.

${ }^{67}$ Engel 1992, p. 319-320.

${ }^{68}$ Engel 1987, p. 789.

${ }^{69}$ Schrand 1999, p. 1456.

${ }^{70}$ Kennedy-Pipe 2004, p. 92.

${ }^{71}$ Zellerer and Vyortkin 2004, p. 442.
} 
house-work, and upgrade and expand day-care"72. Also, the Soviet Union took steps to reduce the expectations from women in the labor force, for instance, the regime required fewer labor days and hours from women. However, this created discrimination and financially harmed women. Another solution, the informal one, was the sharing responsibilities with other women of the same household, kinship, or village. In this way, they helped to carry each other's burden ${ }^{73}$. Planners and academics gave some advice to the Soviet authorities to help handle the double burden. These suggestions were listed as building more nurseries, providing a relatively shorter working day for women, expanding the sectors of the economy which largely attract women, mechanizing existing factories to reduce the number of female manual workers, raising the educational opportunities for women, and encouraging them for further political and social participation ${ }^{74}$.

Creating a socialist state, from zero, was a difficult task. It was an undeniable fact. In addition, some prices should have been paid. However, the price that women had to pay was much more than the she could afford. Therefore, they became the victims of Soviet ideology, because they were expected to be more than they could be.

\subsubsection{What kind of Proletariat was the Central Asian Woman?}

Farnsworth claims that there is an assumption that the Russian socialists were, from prerevolutionary days, actively committed to working for the liberation of women. In fact, he claims that insofar as we can speak of a single attitude for so factionalized a group as the Social Democrats, the opposite was true. The liberation of women, part of the ideological equipment that the Russians inherited from a more humanistic, Western European tradition, was a concept they resisted adopting as a goal. It implied not simply equality for women, but a union of women as a separate group, linked by bonds that transcended those of class. Therefore, the Social Democrats preferred that the liberation of women not to be treated as a specific, revolutionary goal, but rather as an eventual result of the class struggle ${ }^{75}$.

Therefore, one cannot understand the woman question without understanding the class struggle in society, from the perspective of Soviet Union. It was claimed that in the absence of indigenous proletariat in Central Asia, women were perceived as a "surrogate proletariat", very first social basis

\footnotetext{
${ }^{72}$ Engel 1987, p. 795.

${ }^{73}$ Croll 1981, p. 367-368.

${ }^{74}$ Lubin 1981, p. 198-199.

${ }^{75}$ Farnsworth 1976, p. 292-293.
} 
needed by Soviet regime. Not all the scholars agreed about the type of the proletariat, but mostly all of them would see the woman as the lowest segment of the society.

Soviet leaders had the intention to make women into the strongest supporters of Soviet ideology, when the regime freed them from the sanctions of customs and transforming family structure ${ }^{76}$. Edgar disagrees with this. $\mathrm{He}$ points out women could only be the "supplementary proletariat". Because, she insists that women were expected to support the Soviet regime, as they would be emancipated through its policies, but the woman question was not the regime's primary concern. In addition, the main supporters of the regime were poor peasants, not females. ${ }^{77}$ In contradiction to that, Roy indicates that in the absence of real proletariat, women became the "substitute proletariat" 78 .

In the absence of proletariat, the Soviet regime overemphasized gender relations and the struggle between men and women by to create the conditions that Marx drew for the proletariat revolution. The regime tried to stimulate the revolution based on gender relations. However, one cannot deny the importance attached to men, and absence of the women in politics. Therefore, I think, women were the proletariat in the Central Asia, but they were not the main supporters of the regime, as Edgar points out.

\subsection{Political Area}

Massell claims that in Central Asia, women were perceived to be less reliable than men. Moreover, they were seen dangerous due to their potential to consort with the devil. If there was a man, there was no need for the mind of woman. So, in politics, women were not welcomed by local men. Women had constraints and limitations, and so they could not make decisions without the consent of a male. Therefore, they were not seen as sufficient to handle politics $^{79}$. The view of women as emotional and carrying motherly feelings could be seen the obstacle to make them objective policies.

In the mid-1920s, the Communist Party established Turkistan Communist Party's Women's Division in Tashkent. Turkestani delegates were invited to attend a conference in Moscow for Women of the East in the spring of 1921. Division in Turkistan tried to convince Central Asian women to elect delegates for this conference. Some elected delegates had to run away from their families to attend the conference, because they were not allowed traveling alone. When

\footnotetext{
${ }^{76}$ Edgar 2003, p. 133.

${ }^{77}$ Edgar 2003, p. 148.

${ }^{78}$ Roy 2000, p. 79.

${ }^{79}$ Massell 2010, p. 102-105.
} 
they reached Tashkent, they heard the conference was cancelled. However, the women continued their journey to Moscow. They attended the Second International Congress of Communist Women, but as participant. The Russianlanguage journal for Women's Division organizers, Kommunistka, reported, "The visitors' exotic garb, their veils and their unveiling, and their halting speeches received notice, but the Eastern women themselves went nameless" 80 . Therefore, this example was given to show that how Central Asian women could dedicate themselves to politics, if they were given the chance by Soviet officials. They could be a leading force on the political scene, if their potential could be better used as a tool by the Soviet policy makers.

To overcome these constraints, in 1924, women in Kazakhstan and Tajikistan were given the right to vote. In the 1950s, positive discrimination practices were initiated to push more women onto the political scene ${ }^{81}$. Communist system, also, put a quota to ensure women representation in the parliament. However, women were excluded from the political scene. In the $1960 \mathrm{~s}$, and 1970s, fewer than 4 percent of the urban and district party secretaries were women ${ }^{82}$. Although, the regime expected women to be the regime's political fifth column in their society ${ }^{83}$, they were not given many chances.

The failure of the Soviet system to engage women in politics had many reasons. Most importantly, politics was perceived as ruthless, and politicians were expected to take risks. These qualifications were assumed to be the characteristics of men, not women. It was suggested that women with children could not have enough time for and put enough effort into politics. In addition to these perceptions, women's organizations in the Union were not sufficient to make women politically active. Furthermore, Soviet women thought that politics was a dirty business, and should be left to men to handle. Therefore, both men and women had their own reasons to depoliticize women ${ }^{84}$. Moreover, as indicated before; women had to work a double burden in Soviet society, both at home, and in the work place. So, they did not have enough time to be interested in politics ${ }^{85}$. In addition to these, in Central Asia, women were not permitted to join political organizations; either husbands or fathers forbid women to be active in politics ${ }^{86}$. Another very important issue was the regime's

\footnotetext{
${ }^{80}$ Kamp 2002, p. 268-276.

${ }^{81}$ Abazov 2007, p. 221.

82 Pollert 2003, p. 334.

${ }^{83}$ Massell 2010, p. 147.

${ }^{84}$ Abazov 2007, p. 147.

${ }^{85}$ Tedin and Yap 1993, p. 182.

${ }^{86}$ Gorsuch 1996, p. 641.
} 
fear of feminism. Some of the party officials claimed that there were no separate women interests; both men and women workers sharing the same interests was the idea ${ }^{87}$. This point of view made even more difficult to represent the interests of women in the work place through trade unions, and political organizations.

\subsubsection{Zhenotdel}

Zhenotdel (Women's Department of the Communist Party) was established in 1919 with the aim to liberate women through full participation in labor force and socialization of domestic life. Women from different backgrounds shared the same feeling and commitment to liberate women and make them politically active ${ }^{88}$. Only in the mid-1920s women in Central Asia started to join the Communist Party. The Zhenotdel officials went door to door to encourage women to join the branches and be part of public and private life ${ }^{89}$.

Branches of Zhenotdel opened in the Republics of Bukhara and Khiva in 1923 and 1924 and in Ferghana in 1925. The Presidium of the Central Executive Committee of the Soviet Union issued a statement in February 1925 affirming the "rights of women of the Soviet East" to free them from traditional and religious boundaries and to make them politically active members of the society. In addition, propaganda journals like Bezbozhnik u stanka (The Godless at the Workbench) and the Uzbek Kommunist ran articles about the emancipation of Muslim women ${ }^{90}$.

Zhenotdel in Central Asia focused on the transformation of women's status in the public life. Muslim women were supported to attend literacy classes, speak at public meetings, and join party organizations. While there were some successes during the pre-WW2 period, little interest of Moscow to transform the Muslim societies remained as the most important obstacle to the emancipation of women ${ }^{91}$. Another obstacle was the adoption of NEP; the revolutionary goals of the Zhenotdel were harmed by mass unemployment, and deep poverty ${ }^{92}$.

Clements argues that creation of new Soviet woman, portrayed as true believer, revolutionary fighter, builder of a new life, was the utopia, and Zhenotdel would not have achieved this aim ${ }^{93}$. One of the main obstacles was the failure of Zhenotdel workers' definition of the true problems of the Central

\footnotetext{
${ }^{87}$ Goldman 1996, p. 48.

${ }^{88}$ Clements 1992, p. 486.

${ }^{89}$ Corcoran-Nantes 2005, p. 50-53.

${ }^{90}$ Corcoran-Nantes 2005, p. 50-53.

${ }^{91}$ Edgar 2006, p. 257.

${ }^{92}$ Massell 2010, p. 134.

${ }^{93}$ Massell 2010, p. 486-487.
} 
Asian women. They believed that the local women wanted to get rid of the traditions and customs oppressing them without taking into consideration the views of Central Asian women. Since local women were often not in the leadership positions of their local Zhenotdel branches, Central Asian women could not become active agents in defining their own problems and proposing solutions acceptable to them. The opening of the organization was promising, but the result was not satisfactory for the local women. Rather, some undesired consequences arose, such as the murders after the Hujum.

In 1930, Zhenotdel was abolished by Central Committee ${ }^{94}$ because the party ultimately saw that "its idea of "self-activity" for women was "so radical" and "so utopian" that it could not be incorporated into Stalin's redefinition of the revolution"

In the mid-1980s, Mikhail Gorbachev initiated political reforms. He called for the reemergence of women's section under the national Women's Committee. In 1987, there were 24,000 women's councils, and grassroots women's initiatives began to emerge ${ }^{96}$.

\section{Conclusion}

In the 1920s, the Soviet regime tried to be free women from the burdens of traditional way of life, and its symbolic expressions such as the veil. In the 1930 s and 1940s, women were perceived as devoted workers on the way of creating socialism. Until the 1950 s, there was not much discussion on the roles of the women. After the death of Stalin, the woman question returned to the public arena. In 1956, Khrushchev underlined the importance of women's active participation in politics. In the 1980s, especially in education, women's successes were impressive ${ }^{97}$.

So, the changing needs of the regime brought about changes in policies toward women. Therefore, the real intention of the Soviet regime while promoting the emancipation process for women became a controversial issue. On the one hand, some scholars have emphasized ideological concerns such as creating an identity for Soviet people including those in the Central Asian population as the main motivation behind Soviet policies toward Muslim women. Clements, for example, argued that, "women's emancipation was a means to, not a product of, the construction of communism, for the essence of communism was not technology and social organization, but a transformed

\footnotetext{
${ }^{94}$ Massell 2010, p. 495.

${ }^{95}$ Goldman 1996, p. 48.

${ }^{96}$ Zellerer and Vyortkin 2004, p. 443.

${ }^{97}$ Ishkanian 2003, p. 475- 496.
} 
individual" ${ }^{198}$. On the other hand, some others have argued that reforms for the emancipation of women were carried out for the survival of the system and creation of supporters for the regime. Iskhanian, for example, underlined that throughout the Soviet Republics of Central Asia and the Caucasus, local Zhenotdels (mentioned in Zhenotdel part) established women's clubs, workers' clubs, tea-houses (chaykhana), workshops (artel), and evening schools for adult literacy or "illiteracy liquidation centers" to integrate women into the Soviet system. The overarching goal of the Soviet state was not so much to liberate women, but to organize them as a political and economic force that would become workers in the industrialized economy ${ }^{99}$.

Whether motivated by an intention to integrate women into the political and economic system, or by a will to transform them, Soviet officials believed that eliminating local and regional identities, family and religious responsibilities through education, participation in the labor force, and political activism would lead to the weakening of patriarchal structures, and consequently to the emancipation of women ${ }^{100}$. However, the changes put into effect by the Soviet Union did not result in the elimination of local cultural patterns ${ }^{101}$. As Massell explains, there was a huge gap between the existing social structures and the envisioned ones ${ }^{102}$.

The gap mentioned by Massell resulted in the creation of the local interpretation of Soviet policies. For example, Soviet officials assumed that, through men and women working together in the same places, and being economically independent, women would be equal to men. However, Central Asian population adapted this to their way of life. The women did work in the same place with men, but they divided the work place creating separate spaces for each. Another example would be about religious activities. The Soviet Union tried to eliminate religious practices from public life; however, most of the Central Asian women were practicing their religious duties inside the home, ${ }^{103}$ so they were not affected from these kinds of changes, as the way the Soviet officials expected. Therefore, the misinterpretation of the Soviet Union hindered the very essence of the reforms and left little mark behind them. The Soviet officials' interpretation of the history, future generations, and the world around them ${ }^{104}$ made the Soviet system vulnerable, and ineffective. So, as Lubin

\footnotetext{
${ }^{98}$ Clements 1992, p. 494.

${ }^{99}$ Ishkanian 2003, p. 479.

${ }^{100}$ Kennedy-Pipe 2004, p. 95.

${ }^{101}$ Kandiyoti 2007, p. 606.

102 Massell 1968, p. 183

103 Tett 1994, p. 136.

${ }^{104}$ Bonnell 1991, p. 267.
} 
indicates, at the eve of the collapse of the Soviet Union, women were the most conservative, and religious segment of the Central Asian societies ${ }^{105}$.

Going back to the research question, one can argue that gender equality under the law was established formally in Soviet Central Asia; however, its practice shows that gender equality needs much more effort than legislative actions. Although the Soviet regime tried to tackle the woman issue, the main problem for the achievement of desired results was the misguided communication between the Central Asian population and Soviet officials. Soviet leaders and officials presented the problems related to the woman question within their own ideological perspectives. In theory, what was assumed by the Soviet Union is understandable. While emphasizing the subordinate position of women, and the traditional and religious customs, the Soviet Union tried to use the resentments of women to turn them to independent individuals in all spheres of life. However, they failed to understand whether or not the problems they defined were the actual problems preventing women's status to be higher in the society.

One cannot claim that Soviet policies towards women were completely successful or not. What can be claimed is that the policies were pragmatic ones in accordance with the necessities of the time. From the Soviet Union point of view, creation of the defined Soviet person, regardless gender, was the real purpose. Therefore, rather than emphasizing differences, they tried to emphasize common things for all Soviet countries. What was missing in Central Asia was the total understanding of the regime. The people did not know about socialism, they did not know about the consequences of socialism, and the reason behind the reforms related to women. In addition, the regime did not know about Islam, the meaning of Islamic traditions, and it did not try to understand the basic meanings of these traditions for the people of Central Asia.

\footnotetext{
${ }^{105}$ Lubin 1981, p. 201.
} 


\section{BIBLIOGRAPHY}

Abazov 2007 Rafis Abazov, Culture and Customs of the Central Asian Acar \& Güneş-Ayata 2000

Republics, Greenwood Press, London.

F. Acar and A. Güneş-Ayata, Gender and Identity Construction: Women of Central Asia, the Caucasus and Turkey. Leiden; Boston; Köln: Brill.

Alexandrova 1946 Vera Alexandrova, "The Soviet Family", Russian Review, 5, no.2, p. 74-82.

Bonnell 1991

Victoria E. Bonnell, "The Representation of Women in Early Soviet Political Art", Russian Review, 50, no.3, p. 267-288.

Clements 1992

Croll 1981

Barbara Evans Clements, "The Utopianism of the Zhenotdel", Slavic Review, 5, no.3, p. 485-496.

Elisabeth J. Croll, "Women in Rural Production and Reproduction in the Soviet Union, China, Cuba, and Tanzania: Socialist Development Experiences", Signs, 7, no.2, p. 361374.

Dalkesen $2007 \quad$ Nilgün Dalkesen, Gender Roles and Women's Status in Central Asia and Anatolia between the Thirteenth and Sixteenth Centuries, Middle East Technical University, unpublished master thesis.

Edgar 2003

Adrienne Lynn Edgar, "Emancipation of the Unveiled: Turkmen Women under Soviet Rule, 1924-29", Russian Review, 62, no.1, p. 132-149.

Edgar 2006

Adrienne Lynn Edgar, "Bolshevism, Patriarchy, and the Nation: The Soviet "Emancipation" of Muslim Women in PanIslamic Perspective", Slavic Review, 65, no.2, p. 252-272.

Engel 1987

Barbara Alpern Engel, "Women in Russia and the Soviet Union”, Signs, 12, no.4, p. 781-796.

Engel 1992

Barbara Alpern Engel, "Engendering Russia's History: Women in Post-Emancipation Russia and the Soviet Union", Slavic Review, 51, no.2, p. 309-321.

Engel 1999

Barbara Alpern Engel, "Women's Rights a la Russe", Russian Review, 58, no.3, p. 355-360.

Esposito 1996 John L. Esposito, Islam: The Straight Path, Oxford: Oxford Univ. Press.

Evans 1981

Janet Evans, "The Communist Party of the Soviet Union and the Women's Question: The Case of the 1936 Decree 'In Defense of Mother and Child"', Journal of Contemporary History, 16, no.4, p. 757-775. 
Farnsworth 1976

Gulnoza 2005

Goldman 1996

Gorsuch 1996

Ishkanian 2003

Kamp 2002

Kamp 2006

Kandiyoti 2007

Kazemi 2000

Keller 1998

Kennedy-Pipe 2004

Lubin 1981

Massell 1968

Massell 2010
Beatrice Brodsky Farnsworth, "Bolshevism, the Woman Question, and Aleksandra Kollontai", The American Historical Review, 81, no.2, p. 292-316.

Saidazimova Gulnoza, Women \& Power in Central Asia (Part 1): The Struggle for Equal Rights." RadioFreeEuropeRadioLiberty, accessed November 1, 2011, http://www.rferl.org/content/article/1064211.html

Wendy Goldman, "Industrial Politics, Peasant Rebellion and the Death of the Proletarian Women's Movement in the USSR", Slavic Review, 55, no.1, p. 46-77.

Anne E. Gorsuch, "A Woman is Not a Man": The Culture of Gender and Generation in Soviet Russia, 1921-1928", Slavic Review, 55, no.3, p. 636-660.

Armine Ishkanian, "Gendered transitions: the impact of the post-Soviet transition on women in Central Asia and the Caucasus", Perspectives on global development and technology, 2, no.3-4, p. 475- 496.

Marianne Kamp, "Pilgrimage and Performance: Uzbek Women and the Imagining of Uzbekistan in the 1920s", International Journal of Middle East Studies, 34, no.2, p. 263-278.

Marianne Kamp, The New Woman in Uzbekistan: Islam, Modernity, and Unveiling under Communism, University of Washington Press, Seattle.

Deniz Kandiyoti, "The politics of gender and the Soviet paradox: neither colonized, nor modern?", Central Asian Survey, 26, no. 4, p. 601-623.

F. Kazemi, "Gender, Islam and Politics," Social Search 67-2 (Summer 2000), p. 453-474.

Shoshana Keller, "Trapped between State and Society: Women's Liberation and Islam in Soviet Uzbekistan, 19261941", Journal of Women's History, 10, no.1, p. 20-44.

Caroline Kennedy-Pipe, "Whose Security? State-Building and the 'Emancipation' of Women in Central Asia", International Relations, 18, no:1, p. 91-107.

Nancy Lubin, "Women in Soviet Central Asia: Progress and Contradictions", Soviet Studies 33 (2), p. 182-203.

Gregory J. Massell, "Law as an Instrument of Revolutionary Change in a Traditional Milieu: The Case of Soviet Central Asia”, Law \& Society Review, 2, no.2, p. 179-228.

Gregory J. Massell, The surrogate proletariat: Moslem women and revolutionary strategies in Soviet Central Asia, 1919-1929, Princeton University Press, Princeton, N.J. 
Mernissi, Fatma 1991 The Veil and the Male Elite: Feminists Interpretations of Women's Rights in Islam, trans. M.J. Lakeland (New York: Addison-Wesley Publishing Company, Inc.

Michaels 2001

Paula A. Michaels, "Motherhood, Patriotism, and Ethnicity: Soviet Kazakhstan and the 1936 Abortion Ban", Feminist Studies, 27, no.2, p. 307-333.

Nakachi 2006

Mie Nakachi, "N. S. Khrushchev and the 1944 Soviet Family Law: Politics, Reproduction, and Language", East European Politics and Societies, 20, no.1, p. 40-68.

Nantes $2005 \quad$ Yvonne Corcoran-Nantes, Lost voices: Central Asian women confronting transition, Zed Books Ltd., London.

Northrop $2001 \quad$ Douglas Northrop, "Subaltern Dialogues: Subversion and Resistance in Soviet Uzbek Family Law". Slavic Review, 60, no.1, p. 115-139.

Northrop $2004 \quad$ Douglas Northrop, Veiled empire: gender \& power in Stalinist Central Asia, Cornell University Press, Ithaca.

Raga' el-Nimr 1996 "Women in Islamic Law," in Feminism and Islam, ed. Mai Yamani Ithaca Press, p. 87-102

Pascall and Manning 2000

Gillian Pascall and Nick Manning, "Gender and social policy: comparing welfare states in Central and Eastern Europe and the Former Soviet Union", Journal of European Social Policy, 10, no.3, p. 240-266.

Pollert $2003 \quad$ Anna Pollert, "Women, Work and Equal Opportunities in PostCommunist Transition", Work, Employment \& Society, 17, no.2, p. 331-357.

Roy $2000 \quad$ Olivier Roy, The New Central Asia: Geopolitics and the Birth of Nations, New York University Press, New York and London.

Sahadeo \& Zanca 2007 Jefferey F. Sahadeo, and Russell Zanca, (Edts), Everyday Life in Central Asia Past and Present, Bloomington: Indiana University Press

Saktanber \& Özataş-Baykal 2000

Ayşe Saktanber \& Aslı Özataş-Baykal, "Homeland within homeland: Women and the formation of Uzbek national identity". Gender and identity construction: Women of Central Asia, the Caucasus and Turkey, ed. Feride Acar and Ayşe Güneş-Ayata, p. 229-248.

Schrand 1999 Thomas G. Schrand, "The Five-Year Plan for Women's Labour: Constructing Socialism and the 'Double Burden', 1930-1932”, Europe-Asia Studies, 51, no.8, p. 1455-1478. 
Tedin and Fiona Yap Kent L. Tedin and Oi-Kuan Fiona Yap, "The Gender Factor in Soviet Mass Politics: Survey Evidence from Greater Moscow", Political Research Quarterly, 46, no.1, p. 179-211.

Tett 1994 Gillian Tett, “'Guardians of the Faith?': Gender and Religion in an (ex) Soviet Tajik Village," in Muslim Women's Choices: Religious Belief And Social Reality, ed. Camellia Fawzi and Judy Mabro, New York University Press, New York.

Ulrich and Weatherall 2000

Miriam Ulrich and Ann Weatherall, "Motherhood and infertility: Viewing motherhood through the lens of infertility", Feminism \& Psychology, 10(3), p. 323-336.

Women, Islam and the State. Basingstoke and London: Palgrave Macmillan; D. Kandiyoti (ed.) 1991.

Zellerer and Vyortkin 2004

Evelyn Zellerer and Dmitriy Vyortkin, "Women's Grassroots Struggles for Empowerment in the Republic of Kazakhstan", Social Politics: International Studies in Gender, State and Society, 11, no.3, p. 439-464. 